\title{
Makna Arsitektur Taman Kota
}

\author{
${ }^{1}$ Yobbi Ananta Wiratama, ${ }^{2}$ Erwin Ramedhan, ${ }^{3}$ Irwansyah \\ ${ }^{1}$ Badan Penghubung Daerah Provinsi Jawa Timur, ${ }^{2,3}$ Program Magister Ilmu Komunkasi Pascasarjana \\ InterStudi \\ email: 'yobbiananta77@gmail.com
}

\begin{abstract}
Abstrak. Taman kota Ayodia pada dasarnya merupakan ruang publik dan bagian dari ruang terbuka hijau yang dapat digunakan sebagai sarana hiburan rekreasi masyarakat. Masyarakat di Kota Jakarta Selatan saat ini merupakan masyarakat yang sangat modern dengan aktivitas mobilitas yang tinggi sehingga menuntut mereka untuk banyak beraktivitas di luar rumah dan sangat menyita waktu. Penelitian ini menggunakan pemaknaan Semiotika Roland Barthes pada Taman Kota Ayodia. Pemaknaan mencakup denotasi, konotasi dan mitos dari Taman Kota sebagai bentuk komunikasi hiburan. Hasil denotasi memperlihatkan kesamaan dan perbedaan dari gambaran fisik taman kota. Sedangkan hasil konotasi mengalami pergeseran makna estetika taman kota Ayodia. Mitos yang muncul bagi penikmat taman kota seperti menjadi tamu raja.
\end{abstract}

Kata Kunci : Taman Kota, Mitos, Hiburan, Persepsi

\section{Pendahuluan}

Taman Kota Ayodia disediakan untuk memenuhi pelayanan dari pihak penyedia (pemerintah daerah) akan kebutuhan masyarakat terhadap ruang terbuka atau lensekap sebagai tempat aktifitas yang diharapkan dapat memberikan kenyamanan, keamanan, nilai estetik dan sebagainya, (secara psikologis) bagi penggunanya (penduduk kota) dengan kelengkapan fasilitas didalamnya. Di dalam perancangan lansekap, desain merupakan suatu komposisi perpaduan antara tanda, simbol dan sejarah. Tanda yang dihadirkan di dalam lansekap bisa bermacam - macam, mulai dari sculpture, air mancur, tata pola tanaman, jalan setapak, material dan bahkan nama dari area lansekap itu sendiri. (Jorgensen, 1998).

Lansekap tidak hanya terhubung dengan pengalaman kita mengenai lingkungan fisik saja, akan tetapi juga mengenai elemen - elemen lain seperti, cerita rakyat, mitos, simbol - simbol dan gambaran - gambaran. Jorgensen dalam jurnalnya yang berjudul Semiotics in Landscape Design menyampaikan bahwa di dalam desain dan arsitektur itu sudah merupakan hal umum bahwa lingkungan itu merupakan kumpulan tanda - tanda dan kita hidup di dalam dunia tanda. (Jorgensen, 1998). Namun apakah terjadi sebuah simetris pemaknaan antara pengguna dan penyedia terhadap fungsi dari Taman Ayodia? Atau terjadi pergeseran makna yang yang dikonstruksi oleh pengunjung (Taman Kota Ayodia) terhadap Taman Kota Ayodia.

$$
\text { Menurut Belsey }
$$
mengkonseptualisasikan intepretasi sebagai suatu alat untuk menghasilkan sebuah makna. Makna sebuah teks (bentuk) tergantung intepretasi (Pease \& Pease, 2004). Pendapat (Belsey, 1980) dan (Pease \& Pease, 2004) tersebut adalah menjelaskan bahwa sebuah karakteristik sebuah individu tertentu dapat mewakili dan terkait dengan objek lain. Hubungan ini bisa terlihat dalam pendeskripsian tentang persepsi Taman Kota Ayodia. 
Menurut Barthes dalam bahwa pemaknaan sebuah pesan tidak berpegang pada makna proimer, tetapi akan berusaha untuk mendapatkannya dari makna konotasi (Pease \& Pease, 2004). Di dalam pemaknaan terdapat dua sistem pemaknaan yaitu denotasi dan konotasi (Barthes, 1968).

Selain pemaknaan melalui sistem denotasi dan konotasi, pesan pesan juga disampaikan melalui mitos, mitos hadir dengan tujuan menjawab sebuah kenyataan yang ada pada saat ini. Yakni sebuah anggapan bahwa masyarakat mempercayai, apa yang ada dalam sebuah mitos adalah sebuah kebenaran. Namun mitos pada dasarnya bukanlah tentang benar atau tidak benar, terjadi atau tidak terjadi, mitos merupakan sebuah sugesti untuk menjaga sebuah keseimbangan sosial (Barthes, 1957). Karena kondisi sosial suatu masyarakat berubah secara terus menerus dan berkembang, mitos sebagai bagian terintegrasi dan tak terpisahkan dari masyarakat, juga mengalami pergeseran dan perkembangan (Barthes, 1957).

Berdasarkan pada kebiasaan masyarakat dalam menggunakan taman kota sebagai hiburan estetis saja, maka permasalahannya adalah bagaimana makna denotasi dan konotasi yang dikonstruksi oleh masyarakat terhadap Taman Kota Ayodia? Serta bagaimana mitos yang terdapat pada Taman Kota Ayodia muncul di dalam persepsi masyarakat?

\section{Kerangka Konseptual}

\section{Semiotika Dalam Semiologi Roland Barthes}

Ilmu semiologi bertujuan untuk diserap ke dalam trans-linguistik, materi yang berupa mitos, naratif, jurnalisme, atau dari sisi lain. objek tangan peradaban kita, sejauh mereka diucapkan (melalui pers, prospektus, wawancara, percakapan dan bahkan bahasa dalam, yang diatur oleh hukum imajinasi) (Chandler, 2002). Semiotika adalah ilmu yang mempelajari tentang tanda (sign), berfungsi tanda, dan produksi makna. Tanda adalah sesuatu yang bagi seseorang berarti sesuatu yang lain. Adanya peristiwa, tidak adanya peristiwa, struktur yang ditemukan adalah sesuatu, suatu kebiasaan, semua ini dapat disebut benda (Barthes, 1968).

Dalam sebuah sistematik yang dipergunakan untuk menganalisa negosiasi dan makna interaktif tersebut. Denotasi dan Konotasi merupakan dasar dari pemikiran Roland Barthes ini yang berisi mengenai pemikiran tentang dua tatanan Petandaan (Barthes, 1968).

Makna Denotasi merupakan makna kata yang sesuai dengan makna yang sesungguhnya atau sesuai dengan makna kamus, tatanan ini menggambarkan sebuah relasi antara penanda dan petanda di dalam sebuah tanda. Serta antara tanda dengan referennya atau pemikiran yang sudah ada dalam realitas eksternal. menjelaskan lebih lanjut bahwa Denotasi adalah tingkat pertandaan yang menjelaskan hubungan penanda (signifier) dan petanda (signified) pada realitas menghasilkan makna eksplisit, langsung dan pasti (Barthes, 1968).

Makna Konotasi merupakan makna yang bukan sebenarnya dan merujuk pada hal yang lain, makna konotasi adalah makna secara kiasan. Sedangkan konotasi adalah second order of signification tatanan yang pertama mencakup penanda dan petanda yang berbentuk tanda. Faktor yang penting dalam suatu konotasi adalah penanda yang berada pada tatanan pertama (Barthes, 1957). Foto khayalan kita keduanya terkait dengan bentuk, tampilan foto atau dalam penandanya, menjelaskan bahwa setidaknya pada foto memberikan gambaran bahwa apa 
yang dijelaskan oleh makna konotasi adalah bagaimana memotretnya (Barthes, 1957).

Tabel 1. Perbandingan antara Denotasi dan konotasi

\begin{tabular}{ll}
\hline \multicolumn{1}{c}{ Denotasi } & \multicolumn{1}{c}{ Konotasi } \\
\hline Literatur & Pemakaian figure \\
Petanda & Penanda \\
Jelas & Kesimpulan \\
Menjabarkan & Memberikan \\
Dunia Keberadaan & kesan tentang \\
& makna \\
& Dunia mitos \\
\hline
\end{tabular}

Sumber : Arthur Asa Berger, 2000a Media Analysis Techniques. Edisi Kedua.

Penerjemah Setio Budi HH Yogyakarta :

Penerbitan Universitas Atma Jaya, hlm 15

Dalam kajian semiotik, tanda merupakan konsep utama yang dijadikan sebagai bahan analisis di mana di dalam tanda terdapat makna sebagai bentuk interpretasi pesan yang dimaksud. Secara sederhana, tanda cenderung berbentuk visual atau fisik yang ditangkap oleh manusia. Di dalam penelitian ini juga digunakan teori semiotika yang berfokus pada tanda dan cara - cara tanda itu bekerja. Semua ini tergantung pada pengenalan oleh penggunanya sehingga bisa menjadi sesuatu yang dikonstruksikan, maka bisa disebut sebagai tanda. (Barthes, 1968).

Kata mitos secara khusus dapat menjelaskan sebagai sesuatu yang alami dan bahkan abadi, namun sebenarnya merupakan ungkapan visi ideologis dengan nilai historis yang spesifik tentang dunia. Mitos menurut Barthes bukanlah mitos seperti apa yang pada umumnya dipahami selama ini. Mitos merupakan sebuah ilmu tentang tanda dan mitos juga adalah type of speech yaitu tipe wicara atau penyampaian gaya bicara seseorang. Mitos merupakan suatu bentuk pesan atau tuturan yang wajib diyakini kebenarannya namun tidak dapat dibuktikan. Mitos bukanlah konsep atau ide tetapi merupakan suatu cara pemberian arti. Secara etimologis, mitos adalah suatu jenis tuturan dan sudah pasti bukan sembarang tuturan. Suatu hal yang menjadi konsep dan menjadi sesuatu yang harus diperhatikan, bahwa mitos adalah suatu sistem komunikasi, yaitu suatu pesan (message) (Barthes, 1957).

Tabel 2. Pola Keterpautan Bahasa dan Mitos

\begin{tabular}{cc}
\hline $\begin{array}{c}\text { 1. Signifier } \\
\text { (Penanda) }\end{array}$ & $\begin{array}{c}2 . \\
\text { Signified } \\
\text { (Petanda) }\end{array}$ \\
\hline $\begin{array}{c}\text { 3. Sign / Tanda } \\
\text { I. Signifier (penanda) }\end{array}$ & $\begin{array}{c}\text { II. } \\
\text { Signified } \\
\text { (Petanda) }\end{array}$ \\
\hline \multicolumn{2}{c}{ III. Sign / Tanda } \\
\hline
\end{tabular}

Sumber : Barthes, R 2004 Mythologies. Hill and Wang. New York, $1983 \mathrm{HH}$

Penerjemah Nurhadi, A. Sihabbul Millah, Yogyakarta : Kreasi Wacana, hlm. 161

Barthes kemudian memberikan sebuah contoh yang menampilkan cover majalah Paris-Match. Barthes mengatakan kepada seorang rekannya bahwa ia sedang membaca majalah Paris-Match, saat ia berada ditempat pencukuran rambut. Di sampul halaman depan ia melihat gambar seseorang berkulit hitam mengenakan seragam militer Perancis, matanya menatap tajam ke atas dengan gagahnya. Dalam deskripsi contoh ini, kita melihat arti gambar dan lebih lanjut lagi kita dapat melihat makna dari gambar tersebut. Dapat diartikan bahwa kita mampu melihat lebih dari sekedar sebuah gambar. Kita bisa menangkap pesan yang ingin disampaikan dari balik gambar yang dibuat, yaitu Perancis yang merupakan sebuah daerah kekuasaan besar, tanpa membedakan diskriminasi warna kulit, di bawah 
benderanya dan tanpa mempunyai rasa dendam kolonialisme orang berkulit hitam yang digambarkan dalam adegan tersebut mempunyai makna ingin malayani negaranya. Namun lebih lanjut kita dihadapkan oleh sistem semiologi yang lebih besar terdapat pada signifier yang telah dibentuk oleh sistem semiologi sebelumnya yakni seorang berkulit hitam yang sedang memberi hormat, yang memberi signified. Perancis dan militer, yang kemudian memberi sign baru lagi tentang imperialime Perancis (Barthes, 1957).

Mitos adalah bagian penting dari ideologi. Mitos yang dimaksud Barthes bukan seperti mitologi Yunani tentang dewa - dewa. Menurut Barthes, mitos masa kini bukan merupakan konsep, mitos tidak berisi ide - ide atau menunjukkan objek, mitos masa kini mengandung pesan - pesan. Dipandang dari segi struktur, mitos adalah bagian dari parole, sama seperti teks, mitos harus dilihat secara menyeluruh. Mitos adalah unsur penting yang dapat mengubah sesuatu yang kultural atau historis menjadi alamiah dan mudah dimengerti (Barthes, 1957).

\section{Semiotika Arsitektur}

Berdasarkan semiotika, arsitektur dapat dianggap sebagai teks atau tata bahasa. Untuk memahami komunikasi arsitektural dalam semiotika, bisa saja menggunakan model linear dan circular dari teori informasi matematika. Dimana dapat mengindikasikan bahwa arsitektur merupakan interpretasi dari arti atau sebagai medium untuk penyampaian pesan - pesan. Meski dalam bentuk informasi pola - pola (patterns) seni, arsitektur lebih cenderung untuk memberikan bentuk (shape), bukan data angka (Arnheim, 1977).

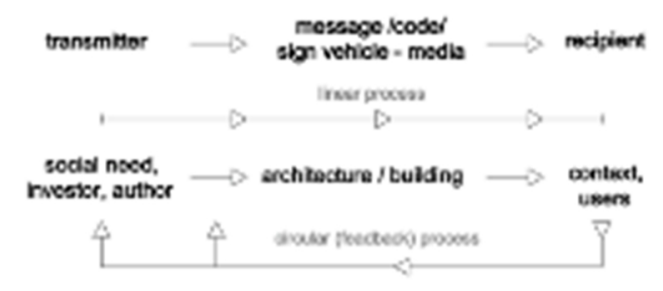

\section{Gambar 1. Linear and circular model from the theories of information - Architecture has been recognized as a means (medium) for conveying information \\ Sumber: S.S. Vukovic, Architectural Communication, 2013}

Di masa lalu, sarana publik mengungkapkan makna bersama melalui konvesi atau kesepakatan bersama yang sudah diakui. Sedangkan pada masa sekarang ini konvensi ini tampaknya digantikan oleh kekuatan komersial dan pencarian untuk ketenaran instan. Perancangan arsitektur publik sekarang diperlukan untuk menjadi patung - patung surealis dan juga sesuatu yang menarik bagi khalayak yang beragam sekaligus provokatif dan praktis namun tanpa konteks penyajian yang bersifat untuk dijadikan agama atau ideologi. (Sondhi, 2015). Desain dalam bentuk idenya adalah untuk mengkodekan arsitektur dengan sebanyak - banyaknya makna referensi silang, sebagaimana dimaksud adalah untuk dapat mengkomunikasikan makna dengan tegas (Jorgensen, 1998). Kejelasan dan variasi makna konotasi pada akhirnya akan bergantung kepada masyarakat dan persepsi mereka berdasarkan kenyataan yang telah dikondisikan sebelumnya dan telah disaring. Dalam mengungkap makna untuk memahami suatu bentuk arsitektur tidak bisa dengan hanya menggunakan satu referensi pemikiran, sebaiknya digunakan referensi pembanding yang lain sebagai penguat ungkapan. (Sondhi, 2015). 


\section{Semiotika Ruang Terbuka}

Menurut sejarah konsep dan pemikiran mengenai keberadaan ruang terbuka hijau sudah ada sejak jaman kerajaan di nusantara, sebagai contoh salah satu fasilitas ruang terbuka pada masa itu dikenal dengan sebutan Alun Alun yang dimaksudkan untuk seorang raja mengumpulkan para prajurit kerajaan untuk berlatih perang dan untuk mengumpulkan para petinggi kerajaan serta rakyatnya. Ruang terbuka yang luas biasanya terletak di tengah tengah keliling dinding kerajaan disertai dengan pepohonan yang rimbun akan tetapi sangat teratur, seiring dengan perjalanan waktu kemudian Alun Alun penempatannya berada tepat di depan pendopo pusat suatu pemerintahan daerah (Paulus, 1917).

\section{Paradigma Semiotika Ruang Terbuka}

Disebutkan bahwa, dengan menggunakan elemen dan konsep dari semiotik, adalah mungkin untuk mengembangkan teori atau model lansekap yang dapat mencerminkan struktur bahasa pikiran dari lansekap itu. Isu utama dalam pemikiran ini adalah: apa yang diungkapkan lansekap? Apa yang diinginkan dari lansekap? Apa yang menjadi biografi lansekap ini? Adakah tekanan, kecenderungan, atau potensi yang jelas untuk dalam perancangannya? Dan lalu apakah tahapan selanjutnya dalam biografinya? (Jorgensen, 1998)

Dalam karya arsitektur menjelaskan bahwa dengan desain yang spesifik, pikiran dengan atmosfir yang mempengaruhi dapat merefleksikan penikmatnya dan nampak jelas dalam representasi literalnya, sehingga memungkinkan untuk mentransfer nilai dunianya. Sebagai contoh mengenai ruang terbuka yang memberikan makna cinta, kesedihan dan keabadian, melalui atmosfir buatan yaitu Taj Mahal mausoleum (Gawlikowska, 2013).

Landscape dalam bentuk taman (garden) diterjemahkan dari bahasa Ibrani, Gan berarti melindungi atau mempertahankan lahan yang ada dalam suatu lingkungan berpagar, Oden berarti

kesenangan, kegembiraan, dan kenyamanan (Laurie, 1986).

\section{Metodologi}

Metode penelitian yang digunakan adalah Qualitative Descriptive. Pendekatan bentuk ini lebih memusatkan diri pada suatu unit tertentu dari berbagai sisi fenomena Taman Kota Ayodia. Kualitatif Deskriptif merupakan penelitian eksplorasi dan memainkan peranan yang sangat penting berdasarkan postpositivisme dengan mengumpulkan, mengungkapkan berbagai masalah dan tujuan dalam menghasilkan hipotesis (Sugiyono, 2008). Serta mengumpulkan informasi pemahaman pengunjung tentang berbagai makna denotasi dan konotasi akan taman kota.

\section{Konseptualisasi}

Penelitian kualitatif deskriptif ini juga merupakan suatu metode yang meneliti status sekelompok manusia, suatu objek, suatu set kondisi, suatu sistem pemikiran dengan tujuan untuk membuat deskripsi, gambaran atau lukisan secara sistematis, faktual dan akurat mengenai fakta - fakta serta hubungan antar fenomena yang diselidiki (Supardan, 2009). Menekankan pada pemaknaan Denotasi, Konotasi dan Mitos yang terbentuk dari kata Ayodhya dan kemudian muncul di dalam masyarakat dalam bentuk taman kota Ayodia dengan batasan fisik taman kota, pergeseran persepsi dan mitos yang muncul. Indikator yang digunakan 
adalah pemahaman responden terhadap fungsi taman kota dan pergeseran maknanya.

\section{Hasil Penelitian Dan Pembahasan}

Ayodhya dalam bahasa Sansekerta adalah "yang tidak akan kalah dalam peperangan", Ayodhya juga dikenal sebagai salah satu kota suci utama dalam bagian Hinduisme yang merupakan agama terbesar ketiga di dunia, Ayodhya memiliki peran sentral dalam epik India kuno yaitu Ramayana, yang dikenal dengan memiliki tokoh protagonis Raja Rama yang diyakini sebagai manifestasi Dewa Wisnu yang berinkarnasi di bumi dan menjelma menjadi pangeran Ayodhya Putera dari Raja Dasarata. Kota Ayodhya ini dikisahkan dibangun oleh Putera Maharaja Manu keturunan Ikswaku dari dinasti Surya, kota Ayodhya terletak di tepi Sungai Sarayu dan merupakan ibukota kerajaan Kosala kuno (Hopkins, 1901).

Didalam deskripsi Kakawin Ramayana terdapat banyak sekali kata Ayodhya tercantum didalamnya, yang konteksnya menggambarkan mitos sebagai berikut :

1. Hana rājya tulya kèndran, kakwèhan sang mahārddhika suçila, ringayodhyā subbhagêng rāt, yeka kadhatwannirang nrpati. Yang mempunyai arti : Ada sebuah istana bagaikan surga, dipenuhi oleh orangorang bijak serta luhur perbuatan, di Ayodhya-lah yang cukup terkenal di dunia, itulah istana Sri Baginda Prabu Dasarata. (Hopkins, 1901).

2. Hayuning swargga tuwi masor, deningayodhyāpurā tiçaya, suka nityakāla menak, ring rēengrēeng towi ring lahru. Yang bisa diartikan : Keindahan surga benar-benar terkalahkan, oleh puri Ayodhya yang tiada bandingannya, di sana selalu dalam keadaan aman sentosa, pada waktu musim hujan maupun pada musim kemarau. (Hopkins, 1901).

3. Akwèhning mūlya kabèh, kanaka rajata lèn maṇik hanangkāna, yāngkēn untunya maputih, gumuyu-guyung swarga sor dénya. Yang bisa diartikan : Berbagai batu-batuan mulia, emas perak beserta permata terdapat di sana, itu laksana gigi keraton Ayodhya yang putih, seolah-olah tersenyum, surga dapat dikalahkannya. (Hopkins, 1901).

4. Hana ta umah kanaka manik, kinulilinganikang taman rāmya, wara kanyakā mamēngamēng, surāpsari tulya ring meru. Yang bisa diartikan : Ada sebuah balai yang bertahtakan permata, dikelilingi oleh taman yang sangat menakjubkan, tempat para gadis-gadis bercengkerama, bagai bidadari di gunung Mahameru atau Himalaya. (Hopkins, 1901).

5. Phațika maṇik ta malahalah, sateja munggwungumah paniñjoan, kadi Ganggā saka Himawān, rūpanya katon sutejā çri. Yang bisa diartikan : Permata manik-manik tak terbilang banyaknya, semua berkilauan terletak pada balai peninjauan, seperti sungai Gangga dari gunung Himawan, kelihatan berkilauan dan sungguh menakjubkan. (Hopkins, 1901).

Dalam buku Imagining Ayodhya : Utopia and its Shadow in a Hindu Landscape (Lutgendorf, 1997) menyampaikan mengenai Dua potongan 
sajak Ayodhya yang terkenal "Rama is king Ayodhya, his capital, and gods and sages hymn their glory". Dan "Oh beautiful for patriot dream, that sees beyond the years. Thine alabaster cities gleam, undimmed by human tears", (Lutgendorf, 1997). Lutgendorf menyampaikan bahwa Ayodhya merupakan tempat tinggal sang raja dan lebih dalam lagi juga menyebutkan bahwa Ayodhya adalah tempat berkumpulnya para dewa. Hal ini memberikan makna bahwa Ayodhya merupakan tempat yang memiliki status yang sangat dipuja (Lutgendorf, 1997).

Ayodhya yang digambarkan sebagai tempat berkumpulnya para dewa, merupakan tempat dengan status yang sangat tinggi dan suci (Lutgendorf, 1997), memiliki ciri - ciri sebagai berikut :

Visualisasi :

1. Terletak tinggi diantara awan awan

2. Berlantaikan batu - batu permata

3. Bersanggah pilar emas

4. Singgasana para dewa

Ayodhya yang digambarkan sebagai tempat tinggal sang raja, merupakan tempat dengan gambaran yang sangat nyaman, aman, tenang dan indah (Lutgendorf, 1997), memiliki ciri - ciri sebagai berikut :

Visualisasi :

1. Bertahtakan emas

2. Dikelilingi oleh taman yang indah

3. Tempat bidadari bercengkerama

4. Dikelilingi aliran sungai

5. Dikelilingi oleh pepohonan yang indah

\section{Taman Kota Ayodia}

Dalam pemahaman makna denotasinya Taman Kota Ayodia dapat dijelaskan secara gamblang, yaitu sebagai lahan terbuka yang berfungsi sosial dan estetik sebagai sarana kegiatan rekreatif, edukasi atau kegiatan lain pada tingkat kota Jakarta Selatan. Juga seperti taman kota pada umumnya yang merupakan bagian sarana publik, tempat evakuasi apabila terjadi musibah gempa, kebakaran dan tempat berkumpul untuk aktifitas formal dan non formal. Taman Kota Ayodia juga merupakan simbol pengembalian fungsi ke awal perencanaan kota yang dibuat pada tahun 1948 dan di renovasi kembali pada tahun 2009 sebagai bagian dari area serapan air serta fungsi penambah oksigen kota (Prabowo, 2017).

Berdasarkan uraian sebelumnya Taman Kota Ayodia secara fungsi mempunyai makna konotasi sebagai tempat yang nyaman, tenang, aman, asri dan bagian dari keindahan kota. Di dalam area Taman Kota Ayodia dapat ditemui, rancangan yang memiliki makna masing - masing seperti tiang tugu, bangku berundak jenis ampitheater, danau buatan, gazebo dan tatanan tumbuhan pada taman (Prabowo, 2017). Jika mengacu pada pengertian kata Ayodhya seperti apa yang tercantum di dalam Kakawin Ramayana tersebut dapatlah kiranya dianalogikan taman ayodia bagaikan keberadaan taman sorga dunia yang sangat menawan, yang pada perencanaan pembangunannya bermaksud untuk membuat para pengunjung dan masyarakat sekitar yang melintasi Taman Ayodia tersebut merasa nyaman.

Pada Taman Kota Ayodia pemaknaan konotasi dapat muncul dari berbagai perspektif pengunjung, hal ini berkaitan dengan pemahaman setiap individu dalam memaknai kegunaan dari taman itu sendiri. Sehingga memicu timbulnya mitos mengenai Taman Kota 
Ayodia yang terbentuk atau terkonstruksi dari sudut pandang penggunanya. Akan tetapi arti kata dalam bahasa Sansekerta yang memiliki arti tidak kalah dalam peperangan lebih terasa jika dilihat dari masa lalu saat dilakukan pembenahan tata ruang kota, adanya pertentangan dua kubu yang sedang berhadapan yaitu pihak pedagang dan pihak pemerintah (Prabowo, 2017).

Dalam buku Pengantar Arsitektur mengungkapkan bahwa perbedaan karakteristik dari bentuk menyampaikan mood yang berbeda dan arti yang berbeda pula. Mengubah karakteristik dari bentuk dapat merubah cara pandang kita terhadap bentuk dan membuat kita merasakan perbedaan dalam desain (Snyder, 1989). Bentuk adalah cara yang kuat untuk berkomunikasi. Para desainer menggunakan bentuk dengan tujuan :

1. Mengelola informasi melalui koneksi dan perpisahan

2. Menyimbolkan ide - ide yang berbeda

3. Menciptakan pergerakan, tekstur dan kedalaman

4. Menyampaikan mood dan emosi

5. Menekankan dan menciptakan entry point dan bagian yang menarik

6. Memberikan arah pada mata dari satu elemen desain ke elemen desain selanjutnya

Dalam hirarkinya terdapat tiga jenis bentuk dasar, yakni bentuk geometris, bentuk natural dan bentuk abstrak. Maka dalam penelitian Taman Kota Ayodia ini dijumpai beberapa elemen rancang yang memiliki makna masing - masing, yaitu :

\section{A. Layout Taman Kota Ayodia :}

1. Tata letak yang hampir menyerupai segi lima dengan sudut yang alami di dalam bentuk geometris, adalah bermaksud untuk menunjukkan keteraturan dan efisiensi yang dipadukan dengan kondisi posisi situs aslinya.

2. Kontur taman yang bersifat menurun dan memusat, menunjukkan keindahan yang tidak melawan kondisi alam awalnya dengan sifat menampung air, dan menampung aktivitas yang berjalan dalam taman tersebut.

B. Desain Tugu Taman Kota Ayodia :

1. Jumlah enam tugu berderet lurus menyampaikan, kekuatan keseimbangan dan poros penjuru.

2. Ketinggian tugu yang dibuat sama persis dengan ukuran 5,5 meter bermaksud menyampaikan suatu junjungan atau penopang.

3. Lampu hias penerang diatas tugu dimaksud untuk menyampaikan kejayaan dan penghormatan.

C. Danau buatan Taman Kota Ayodia :

1. Posisi danau pada tengah lay out, menyampaikan maksud sebagai pengundangan, penampungan dan penerimaan.

2. Bentuk danau yang berlekuk alami, menyampaikan maksud menyatu dengan alam atau menghormati alam.

D. Gazebo Taman Kota Ayodia :

1. Dua bangunan gazebo yang terletak berseberangan bertujuan untuk menyampaikan pengawasan atau pemantauan terhadap pemandangan dan aktivitas yang ada di dalamnya. 
2. Bangunan gazebo yang terbuka (tanpa dinding) bertujuan menyampaikan kebebasan dan terbuka bagi siapapun

\section{E. Jalan setapak (jogging track):}

1. Jalan setapak yang berlekuk alami, menyampaikan tujuan untuk menyatu dengan alam dan tidak melawan bentuk kontur aslinya.

2. Tapak lintasnya yang bertemu dengan jalan akses masuk, menyampaikan maksud kemudahan akses dan sirkulasi yang nyaman bagi pengunjungnya.

\section{F. Tempat duduk berundak :}

1. Tempat duduk yang dirancang pada tengah lokasi site dengan jumlah tujuh tingkatan, bertujuan untuk memberi kemudahan pada pengunjung dalam menikmati keindahan taman tanpa ada gangguan pandangan.

2. Bentuk rancang yang menyerupai busur bertujuan untuk memberikan fokus pandangan pada pusat site taman.

G. Tanaman dan tumbuhan :

1. Tanaman perdu pendek dan tanaman tinggi sedang digunakan sebagai penegas garis batas antara danau dan jalan setapak, bertujuan untuk memberikan keindahan, kenyamanan dan keamanan bagi pengunjung.

2. Tumbuhan tinggi dan besar digunakan sebagai pelindung dari terik matahari dan sebagai pereduksi suara (sound/noise barrier), bertujuan untuk memberikan keindahan, kenyamanan dan ketenangan bagi pengunjung.

\section{Analisis Deskriptif Persepsi Pengunjung Terhadap Mitos Keberadaan Taman Kota Ayodia}

Mitos merupakan sistem komunikasi dan mitos juga adalah sebuah pesan, oleh karena itu membenarkan prasangka seseorang bahwa mitos dapat berupa objek, konsep ataupun ide. Mitos adalah sebuah cara pemaknaan, sebuah bentuk. Dan hal ini mengharuskan untuk menandai batasan historis sebagai syarat penggunaannya. Kendati demikian pertama - tama yang harus dipahami adalah mitos sebagai sebuah bentuk. Mitos bukan ditentukan oleh objek pesannya, melainkan oleh bagaimana cara mitos itu menyampaikan pesannya sendiri dan juga menekankan bahwa, "Kita hidup tidak diantara benda benda melainkan dari opini - opini yang sudah diyakini sebelumnya" (Barthes, 1972).

Kemudian apabila dikaitkan dengan fakta yang diperoleh dari hasil observasi dan wawancara di lapangan. Maka hasil untuk memberikan rasa kebanggaan menjadi "tamu raja" dan untuk menarik minat pengunjung Taman Kota Ayodia masih bertolak belakang dengan rencana, visi dan misi dengan dibangunnya Taman Kota Ayodia. Taman kota yang dibangun sebagai tempat untuk menampung kegiatan dan hiburan bagi masyarakat, justru belum menjadi perhatian sepenuhnya bagi masyarakat.

Mitos Ayodhya yang merupakan tempat tinggal para raja dan tempat berkumpulnya dewa - dewa (Lutgendorf, 1997), dalam esensi sarana komunikasi hiburan yang ditawarkan oleh Taman Kota Ayodia menjadi hilang dengan adanya kendala fasilitas 
yang disiapkan di dalamnya, desain yang indah dan asri belum bisa mewakili rasa aman dan nyaman bagi pengunjung. Target pengunjung yang seharusnya bisa layak bagi semua kalangan menjadi hanya terbatas, hanya bisa nyaman bagi kalangan yang dominan laki - laki. Seharusnya taman kota yang dihadirkan mampu memberikan hiburan, keamanan, kenyamanan dan tercapainya simbol kebanggaan sebagai "tamu raja" bagi masyarakat kota.

Jadi sebaiknya apa yang menjadi pesan atau ide awal dari visi dan misi Taman Kota Ayodia sebagai sarana komunikasi hiburan malah menimbulkan banyak persepsi dikalangan pengunjungnya dalam kunjungannya ke taman ini, sehingga belumlah dapat terealisasikan dalam konteks fasilitas taman kota sebagai sarana hiburan umum yang mencerminkan mitos Ayodhya dalam esensi Sansekerta pada ephos Ramayana.

\section{Analisis Deskriptif Kebutuhan Hiburan Pengunjung Terhadap Penerapan Mitos Ayodhya pada Taman Kota Ayodia}

Sebagaimana peneliti mengkaji penerapan Taman Kota Ayodya sebagai sarana komunikasi hiburan, mengacu pada hasil observasi dan wawancara yang dilakukan pada nara sumber sebelumnya. Maka wajar apabila peneliti menilai, sudah seharusnya pihak penyedia sarana umum dalam hal ini pemerintah, melakukan evaluasi tahap akhir terlebih dahulu mengenai fasilitas penunjangnya sebelum taman kota dibuka untuk umum. Hal ini untuk memastikan, apakah taman kota sebagai pemberi dan penampung hiburan bagi masyarakat dapat diterima dan diapresiasikan dengan sama oleh semua calon pengunjung.
Selanjutnya peneliti menganalisis dan mendeskripsikan data berdasarkan formulasi strategi, seperti yang disampaikan dalam konsep Semiotics in Landscape (Jorgensen, 1998) disebutkan bahwa, dengan menggunakan elemen dan konsep dari semiotik, memungkinkan untuk lebih mengembangkan teori atau model lansekap yang dapat mencerminkan struktur bahasa pikiran dari taman kota itu. Dengan isu utama dalam pemikiran ini adalah: apa yang diungkapkan taman kota? Apa yang diinginkan dari taman kota? Apa yang menjadi biografi taman kota ini? Adakah tekanan, kecenderungan, atau potensi yang jelas untuk dalam perancangannya? Dan lalu apakah tahapan selanjutnya dalam biografi taman kota ini?.

Kebutuhan yang dipenuhi suatu sarana dalam hal ini taman kota bisa menjadi lebih luas lagi. Pengunjung perlu adanya keterikatan emosional antara sarana hiburan dengan aktivitasnya sehingga pada akhirnya bisa memunculkan sentuhan emosional. Dan salah satu unsur yang dapat membuat taman kota berhasil menjadi sarana komunikasi hiburan bagi masyarakat adalah terakomodirnya kegiatan - kegiatan dalam fasilitas hiburan ini dengan jaminan kondisi yang terasa meyakinkan dan menjamin rasa aman dan nyaman bagi pengunjung sesuai dengan mitosnya.

\section{Kesimpulan}

Taman Ayodia sebagai salah satu taman dengan desain terbaik di Jakarta Selatan memiliki karakteristik yang bisa disebut sebagai ikon kota. Dengan harapan Taman Kota Ayodia dapat memberikan nilai tambah yang nyata baik berupa nilai prestisius ataupun nilai kebanggaan bagi masyarakat setempat, hal ini secara umum bisa dinyatakan atau diwujudkan. Mitos nama Ayodhya seharusnya 
menjadi dasar dari perencanaan Taman Kota Ayodia, yaitu aman, nyaman dan memberikan kebanggaan. Akan tetapi pada sebagian masyarakat pengunjung khususnya warga yang mengerti akan kondisi setiap harinya terutama para lanjut usia dan wanita, masih merasakan adanya bayangan rasa tidak aman (insecure) dan kurang nyaman (uncomfortable). Disaat ruang terbuka hijau seperti Taman Kota Ayodia beserta keindahannya mengundang pengunjung lain yang sifatnya lebih memberikan kesan mengganggu, seperti pengamen dan preman musiman yang sedang mabok pada jam malam dan terkadang juga ada disiang hari membuat pengunjung lain untuk pergi meninggalkan taman dengan terpaksa. Kurangnya perhatian petugas keamanan dan kantor administratif untuk tempat melakukan pelaporan, menjadikan kurangnya nilai keamanan dan kenyamanan Taman Kota Ayodia.

Persaingan desain taman kota sekarang menjadi tolok ukur perkembangan majunya suatu kota, semua berlomba - lomba memberikan kenyamanan bagi pengunjung kotanya, dalam penelitian ini yang dimaksud salah satunya adalah taman kota. Mulai dari fitur air mancur bergerak, open wifi, toilet umum yang bersih dan terawat, sampai pemenuhan kebutuhan dasar air minum bersih bagi pengunjung taman. Sungguh sangat disayangkan hal ini masih menjadi kendala bagi para pengunjung, air mancur yang sering tidak beroperasi, wifi masih harus berbayar belum sepenuhnya free service karena masih menggunakan fasilitas wifi id, toilet masih minim jumlahnya dan kurang terawat serta tidak adanya petugas kebersihan toilet yang ditugaskan untuk minimal standby sesuai waktu operasional. Taman Kota Ayodia sebagai ikon kota kebanggaan Jakarta selatan, belum sepenuhnya dapat memenuhi mitos Ayodhya pada ephos Ramayana. Karena taman ini belum dapat memberikan kenyamanan maksimal dalam bentuk gambaran pengunjung sebagai tamu raja, ataupun pengunjung sebagai raja. Bagi pengunjung rutinnya ataupun pengunjung dari luar Jakarta, pihak penyedia belum bisa memberikan atau menumbuhkan hubungan emosional antara sarana Taman Kota Ayodia dengan pengunjungnya.

\section{Daftar Pustaka}

Buku :

Arnheim, Rudolf. (1977). The Dynamics of Architectural Form, University of California Press, Los Angeles, USA.

Barbara, Allan and Pease. (2004). The Definitive Book of Body Language : How to Read Others' Thoughts by Their Gestures, Pease International, Australia.

Barthes, Roland (1968) Element of Semiology, Hill and Wang Printings, New York 1968.

Barthes, Roland (1968) Elemen-Elemen Semiologi, Jalasutra, Yogyakarta.

Barthes, Roland (1957) Mythologies, Twenty-Fifth Printing, United State of America 1991.

Chandler, Daniel. (2002). Semiotics for Beginners, Routledge \& Kegan, London.

Creswell, John. W. 2002. Research Design: Desain Penelitian Pendekatan Kualitatif dan Kuantitatif. Kik Press Jakarta.

Danesi, Marcel. (2010). Pesan, Tanda, dan Makna : Buku Teks Dasar Mengenai Semiotika dan Teori Komunikasi. Jalasutra, Yogyakarta.

Hall, Stuart, (1980). Encoding/Decoding The Media and Language, Hutchison Print, London. 
Hopkins, E. W. (1901). The Great Epic of India, Its Character and Origin, Yale University, Cambridge USA.

Laurie, Michael. (1986). An Introduction to Landscape Architecture, American Elvesier Publishing Co, Inc., New York.

Piliang, Yasraf Amir. 2012. Semiotika dan Hipersemiotika : Kode, Gaya, dan Matinya Makna, Edisi ke Empat. Matahari, Bandung.

Preziosi, Donald. (1983). Minoan Architectural Design, Approach to Semiotics, Mouton Publisher, Amsterdam.

Sugiyono. (2008). Metodologi Penelitian Kuantitatif, Kualitatif dan $R \& D$. Alfabeta, Bandung.

Snyder, C. James, (2000). Pengantar Arsitektur, PT. Erlangga, Jakarta Timur.

\section{Jurnal :}

Gawlikowska, P. Anna. (2013). From Semantics to Semiotics. communication of Architecture, Swiss Federal institute of technology, Switzerland, pp. 58.

Handinoto, (1992). Alun-Alun Sebagai Identitas Kota Jawa, Dulu dan Sekarang, Universitas Petra, Surabaya, pp. 3-10.

Hendarto, R. Mulyo (1997). Teori Perkembangan dan Pertumbuhan Kota, Makalah Diskusi Rutin Fakultas Ekonomi, Semarang, pp. 4. Jogersen, Karsten (1998). Semiotics in Landscape Design, Landscape Review, Norway, 1, pp. 41-44

Sondhi, Priyanka. (2015). Architecture as Communication: A Study of the role of Form, Function and Context in evoking Meaning, Rochester Institute Of Technology, New York, pp. 91-112.

Vuckovic, S. S. (2013). Architectural Communication: Intra and Extra Activity of Architecture, University of Montenegro, Montenegro, pp. 6869.

Widyaningsih \& Nikken Setyowati. (2001). Relevansi Preferensi Penduduk Terhadap Fasilitas Kota Yang mempengaruhi Faktor Perkembangan Kota.

\section{Data Online :}

Ayodhya and The Research on the Temple of Lord Rama :

https://www.stephen-

knapp.com/ayodhya and the resear ch_on_the_temple_of_Lord_Rama.h tm

Ayodhya Is Lord Rama's Birthplace : https://swarajyamag.com/culture/ayodh ya-and-rama-who-said-what

Manas Religious Texts of India Ramayana :

http://www.sscnet.ucla.edu/southasia/R eligions/texts/Ramaya.html Communication as a Field : http://onlinelibrary.wiley.com/doi/10.11 11/j.1468-2885.1999.tb00355.x/pdf Mass Comunication Theory : https://masscommtheory.com/2010/02/2 7/schema-theory-a-quickbackground/ 